\title{
Evidence for Northeast Flowing lee in the Lee of the Sandwich Range, Now Hampshire
}




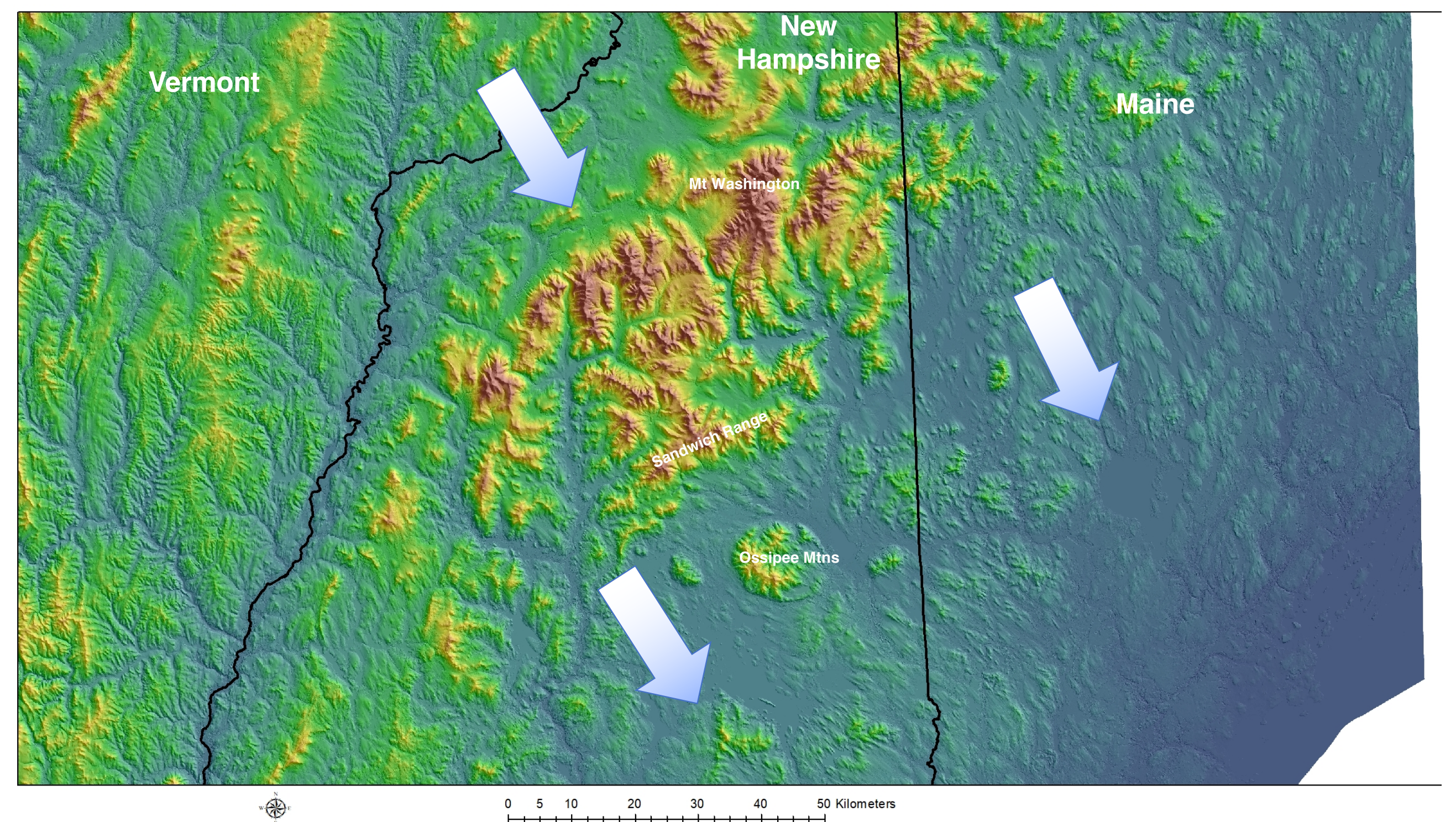




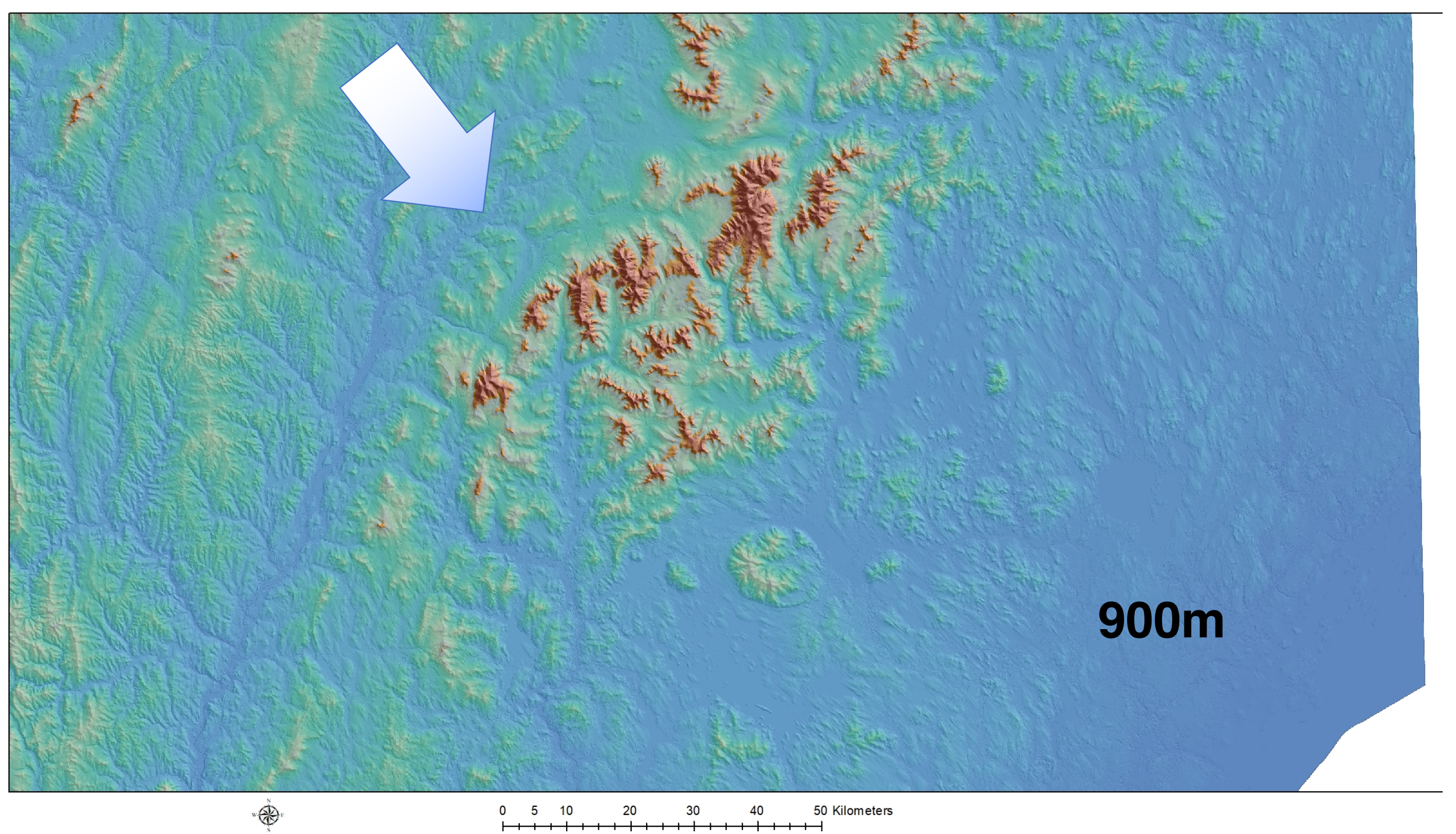




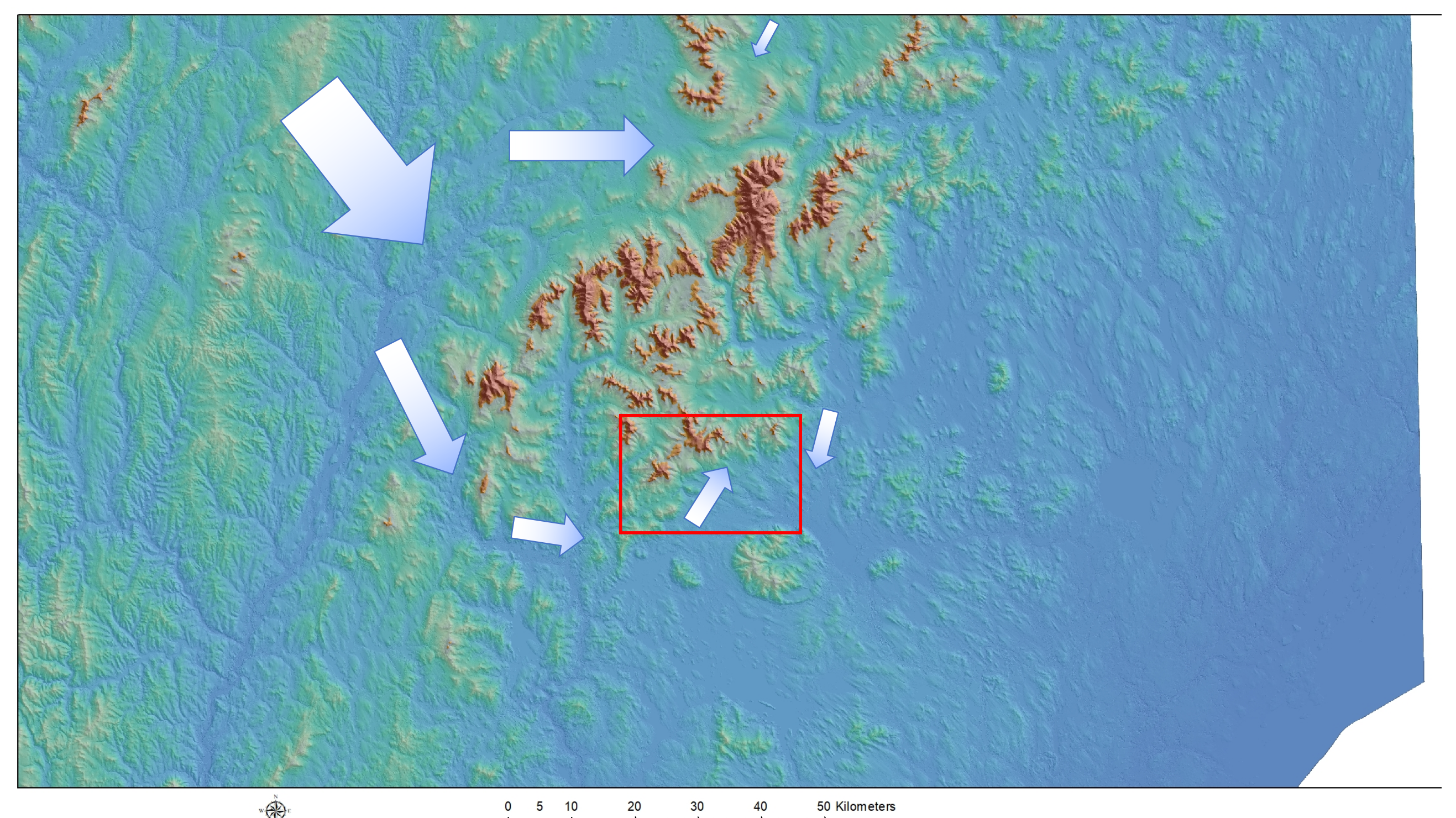




\section{How do we determine ice flow direction?}

- Striations - limited exposures - local influence

- Large Linear features - drumlin, flutes etc.

- Digital Elevation Models (DEM's)

- DEM (10m) and LiDAR based DEM (1m)

- Proper use of hillshading is critical

NE, NW, Slope, Cluster Hillshade, Multi Directional Oblique Weighted Hillshade (MDOW, Terrain Tools). 


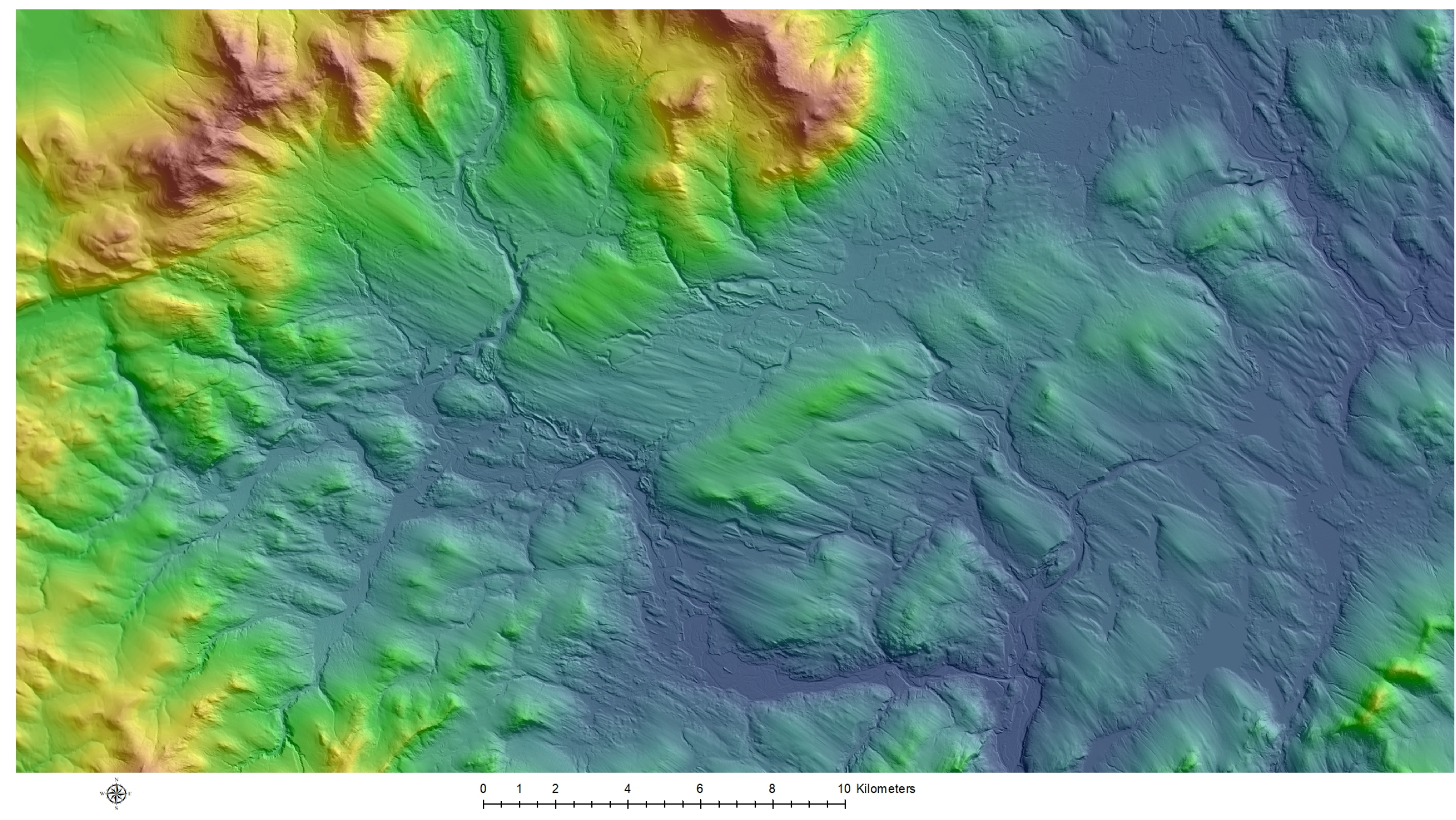




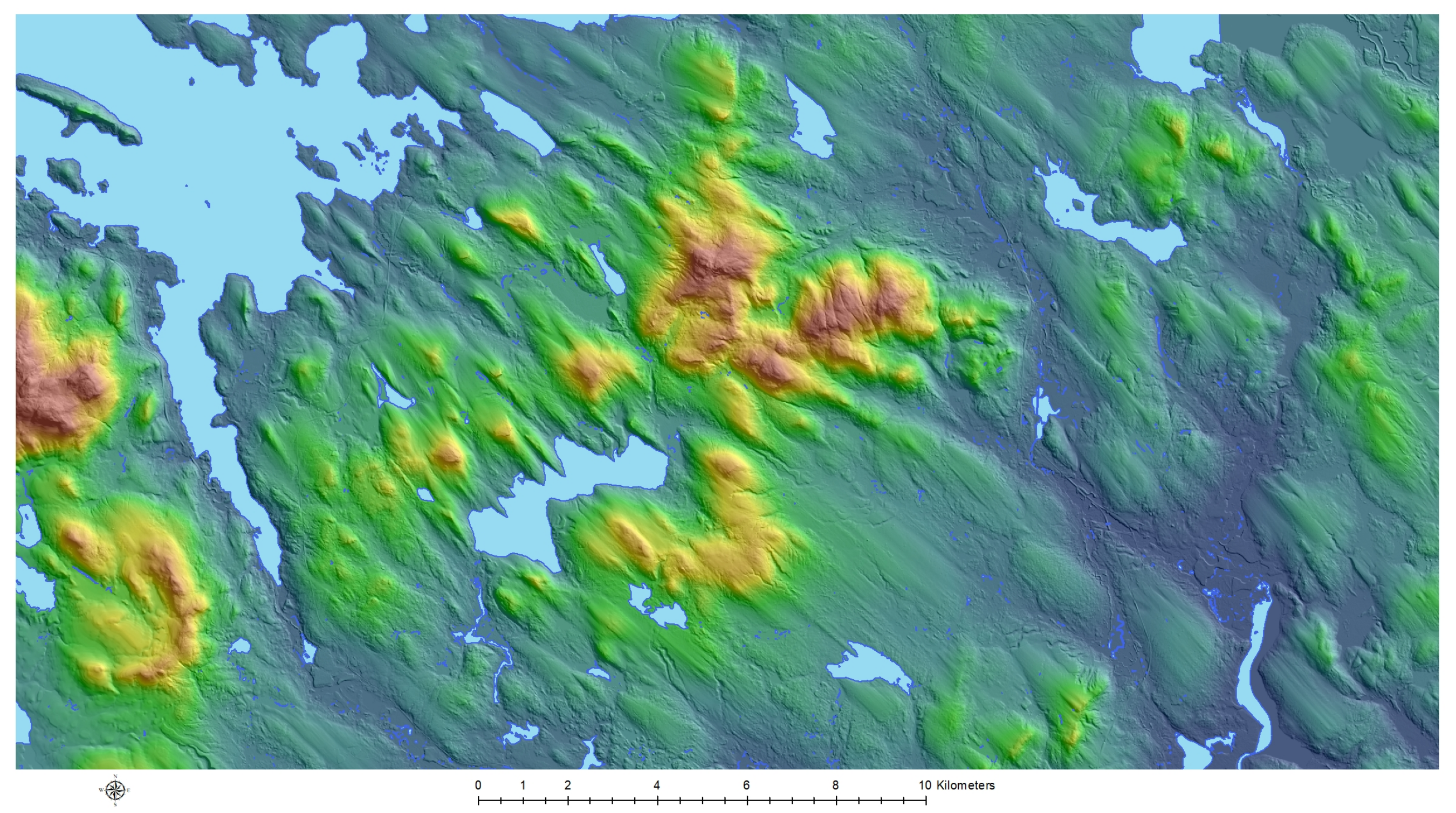




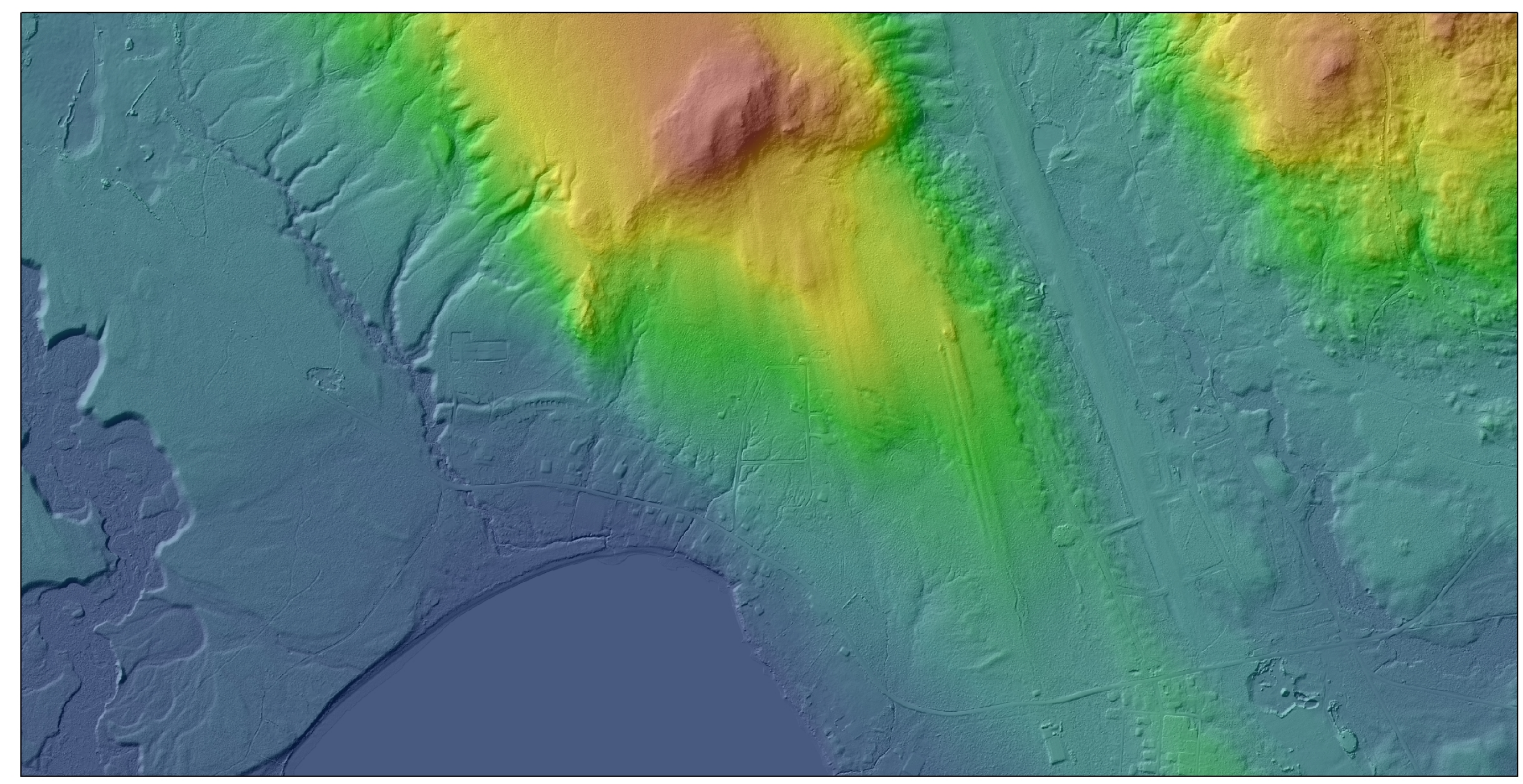

需。

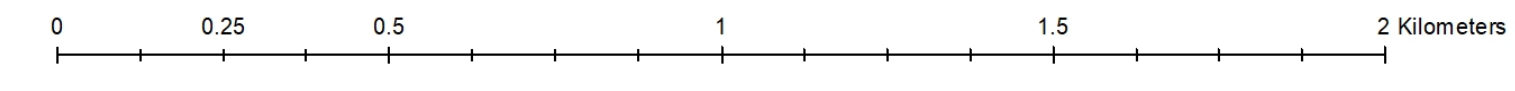




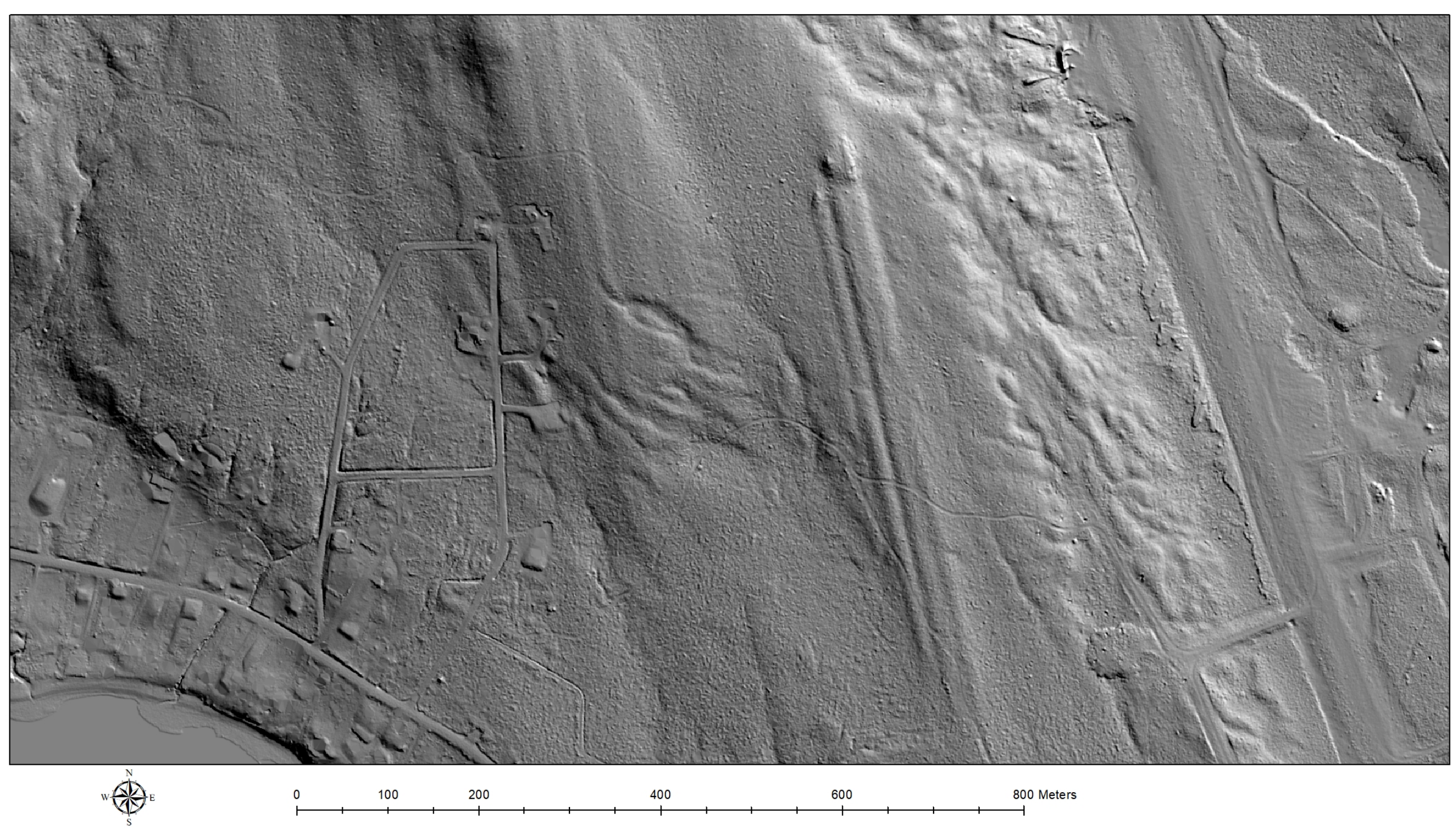




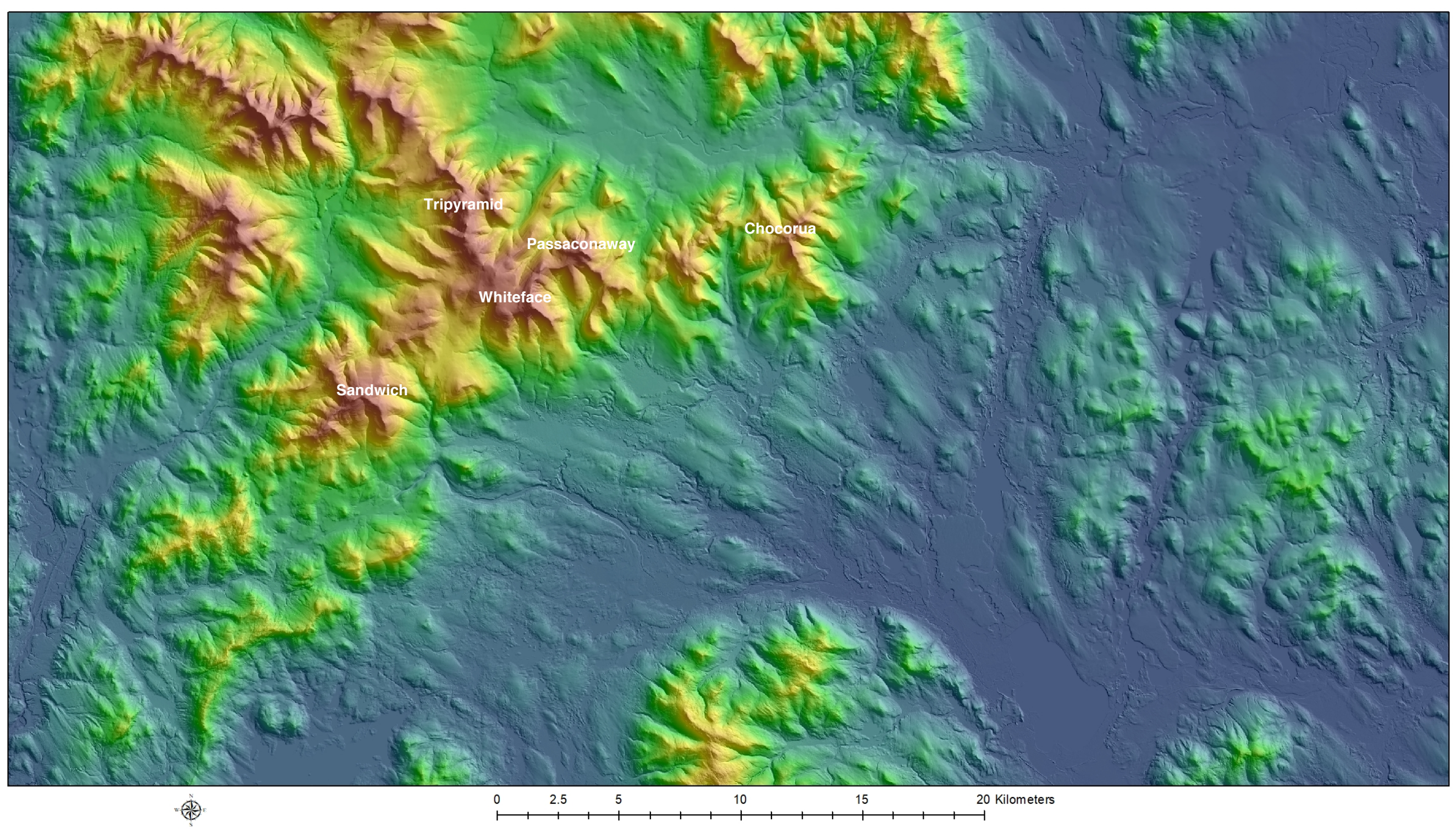




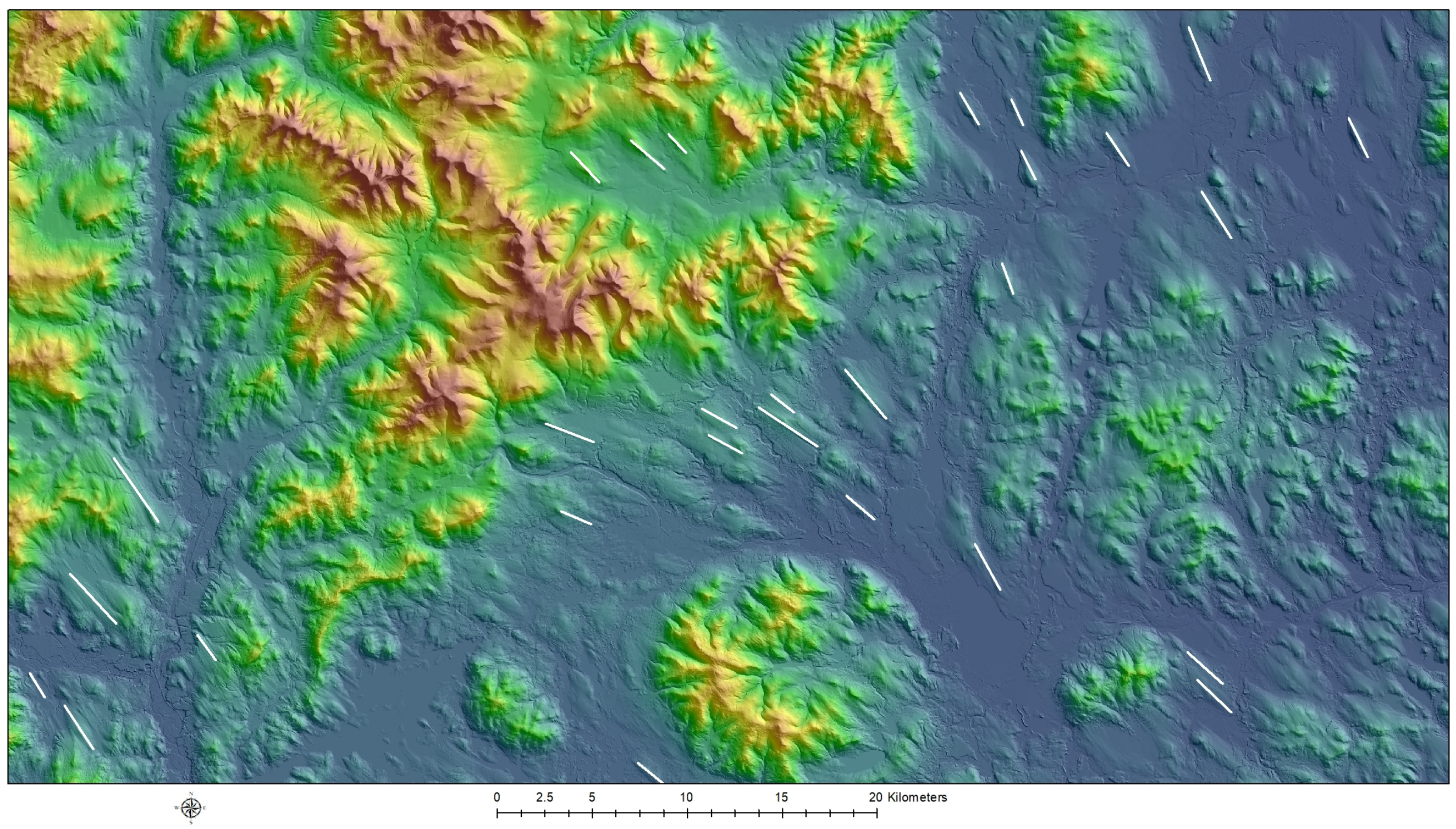




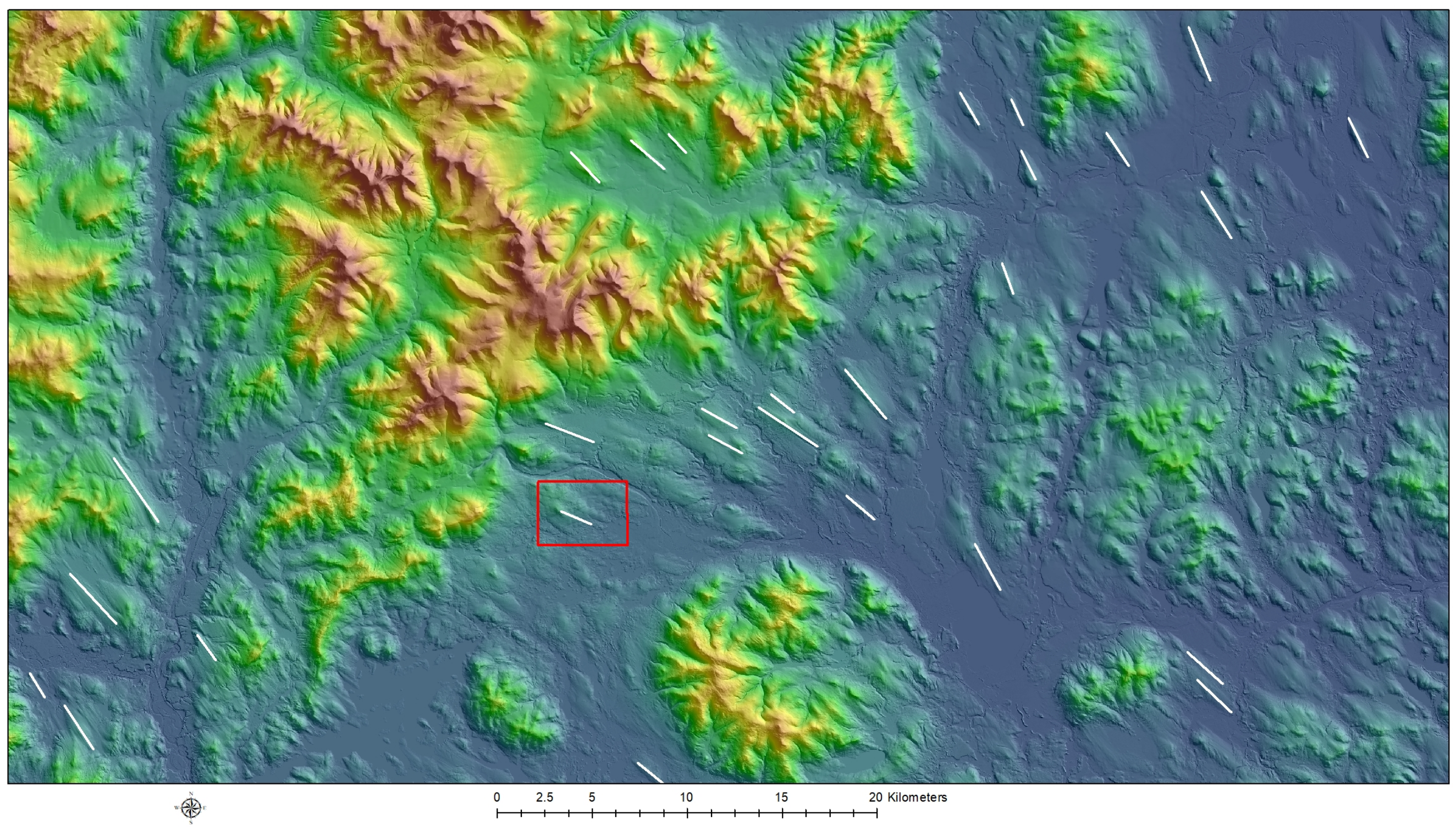




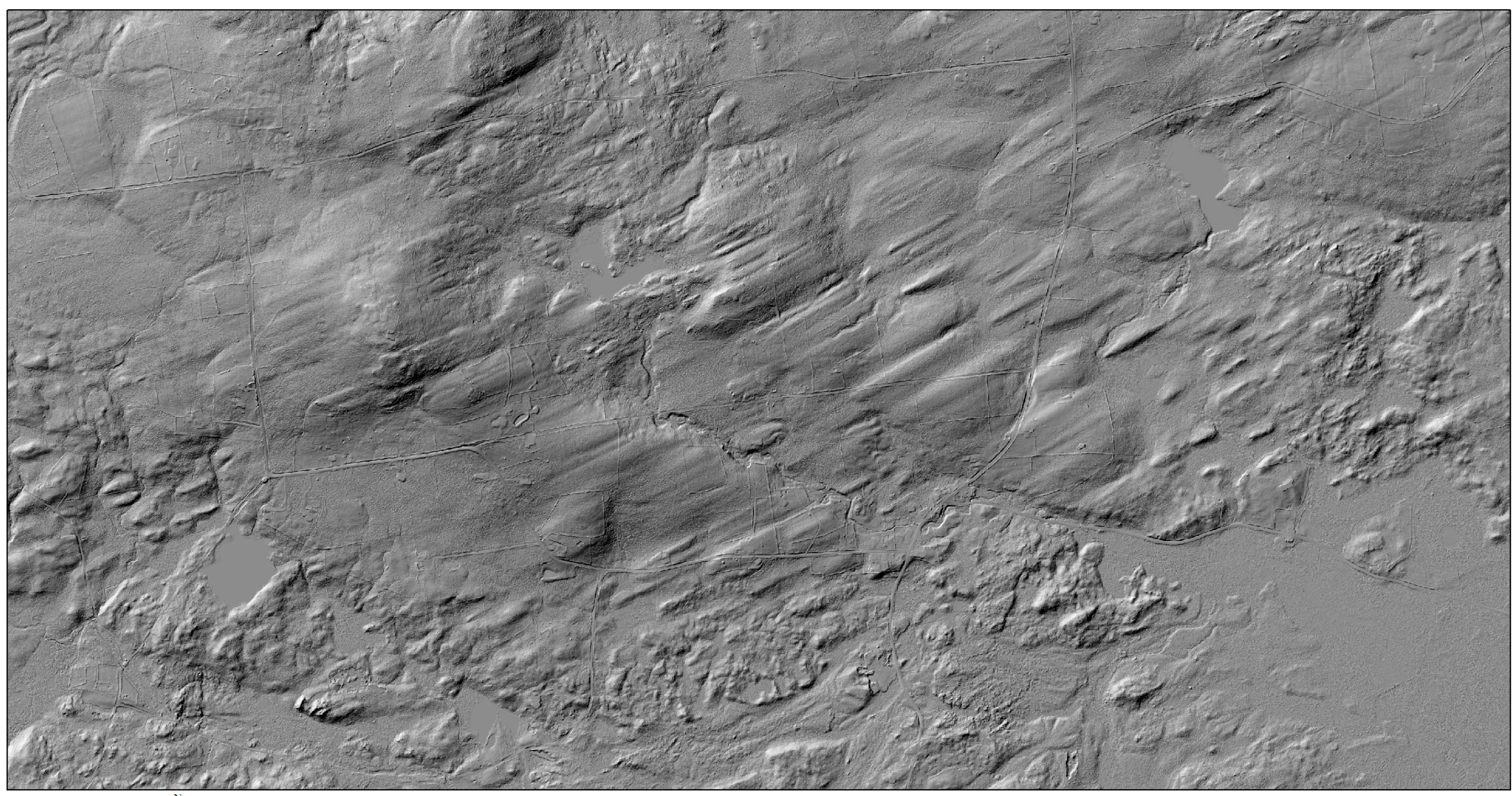

“雨。

$+250, \quad 500$

1,000

1,500

2,000 Meters 


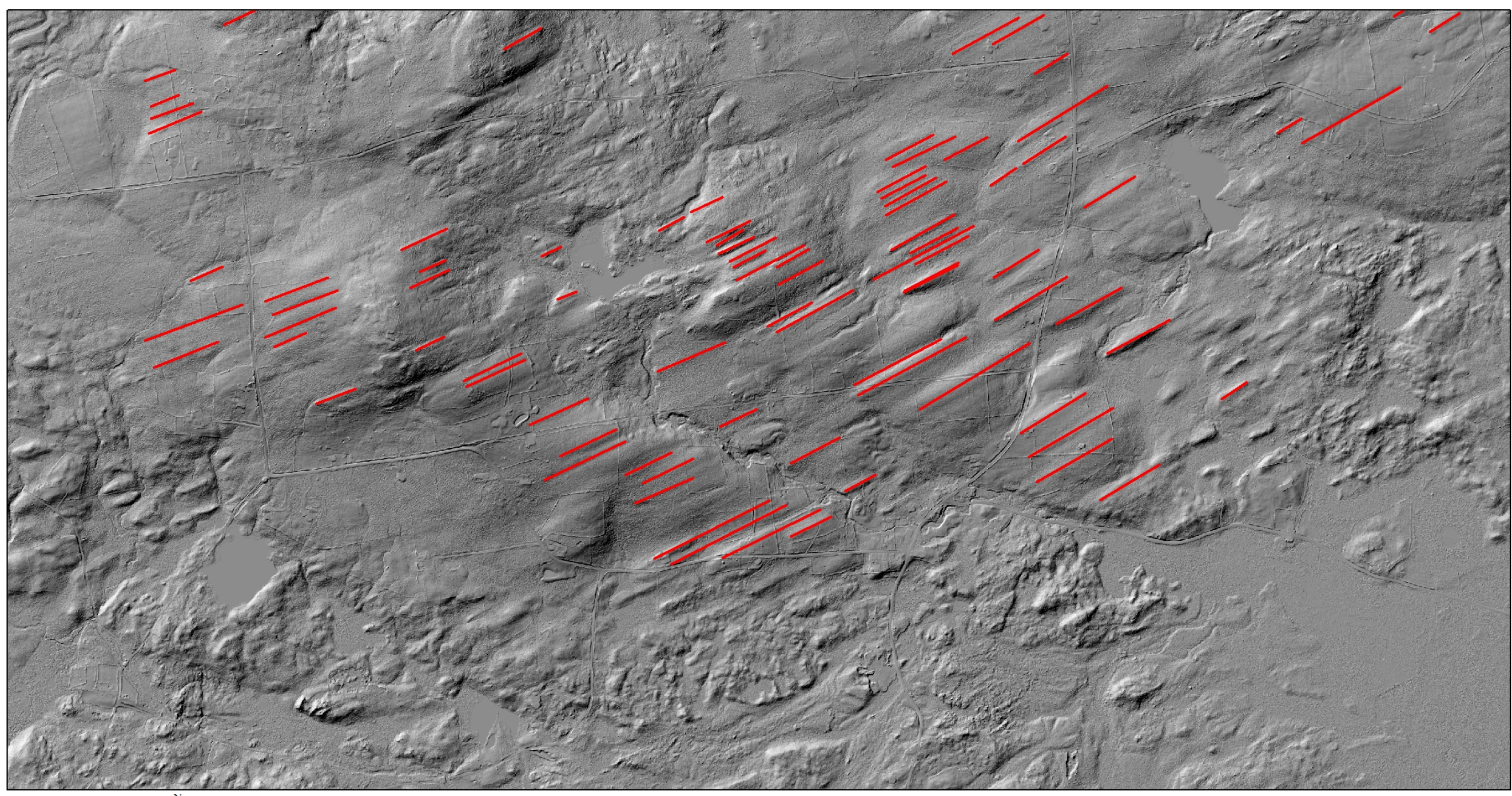

“雨。

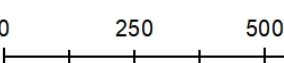

1,000

1,500

2,000 Meters 


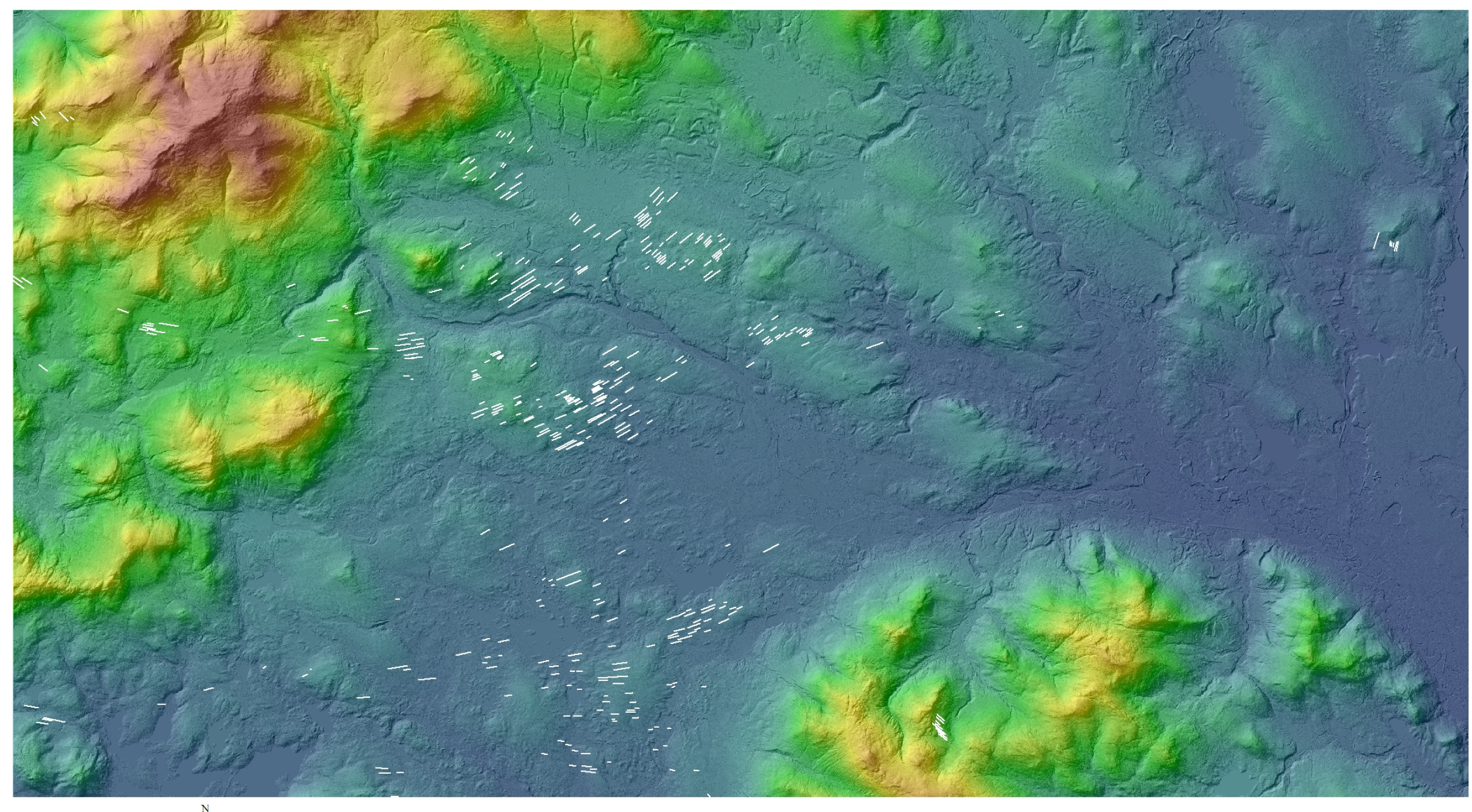

"需。

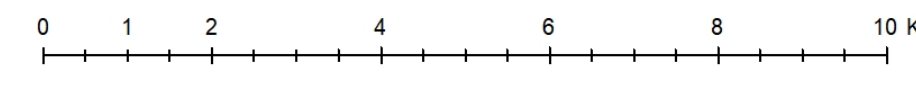




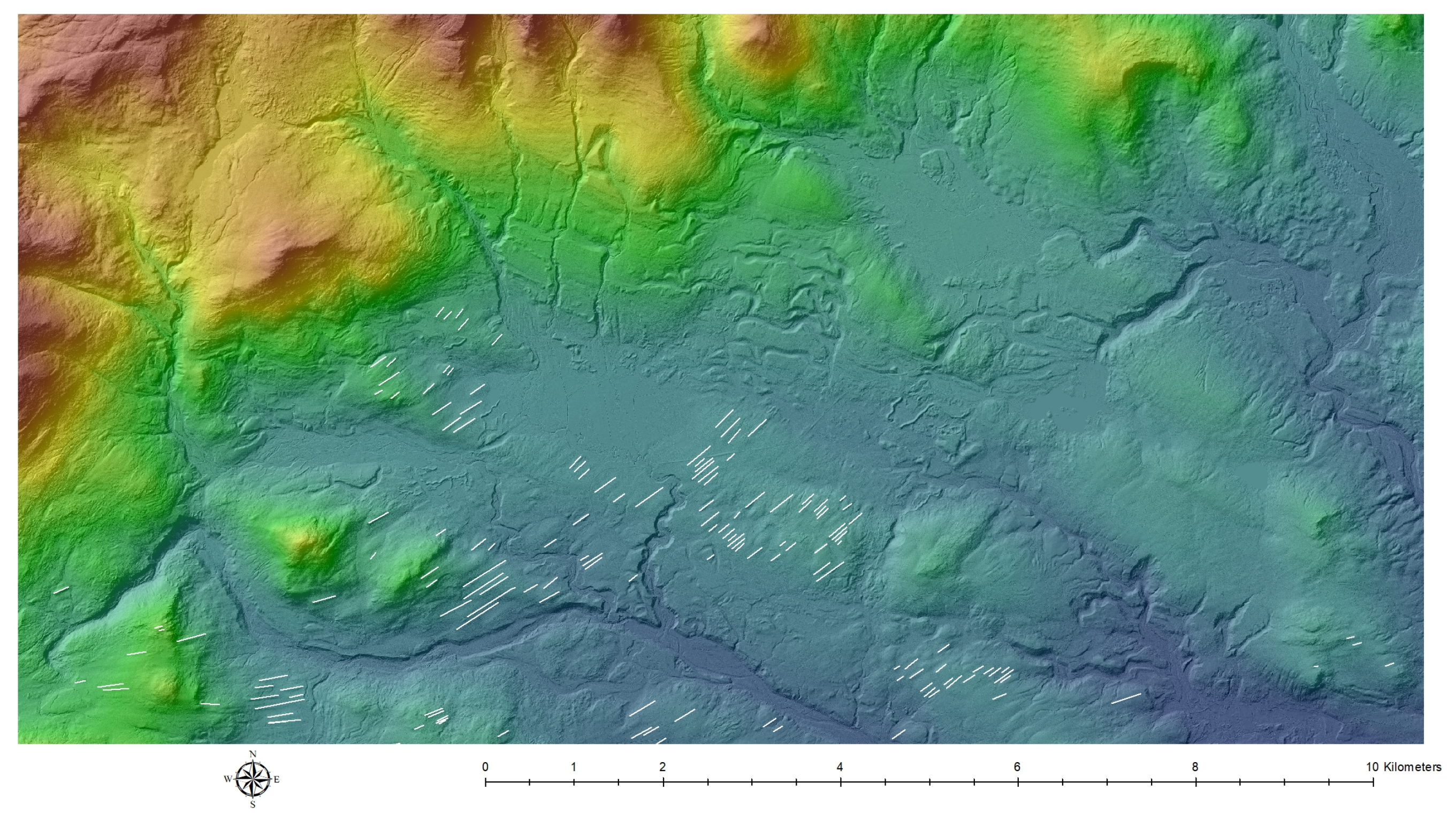




\section{Ice Margin Features}
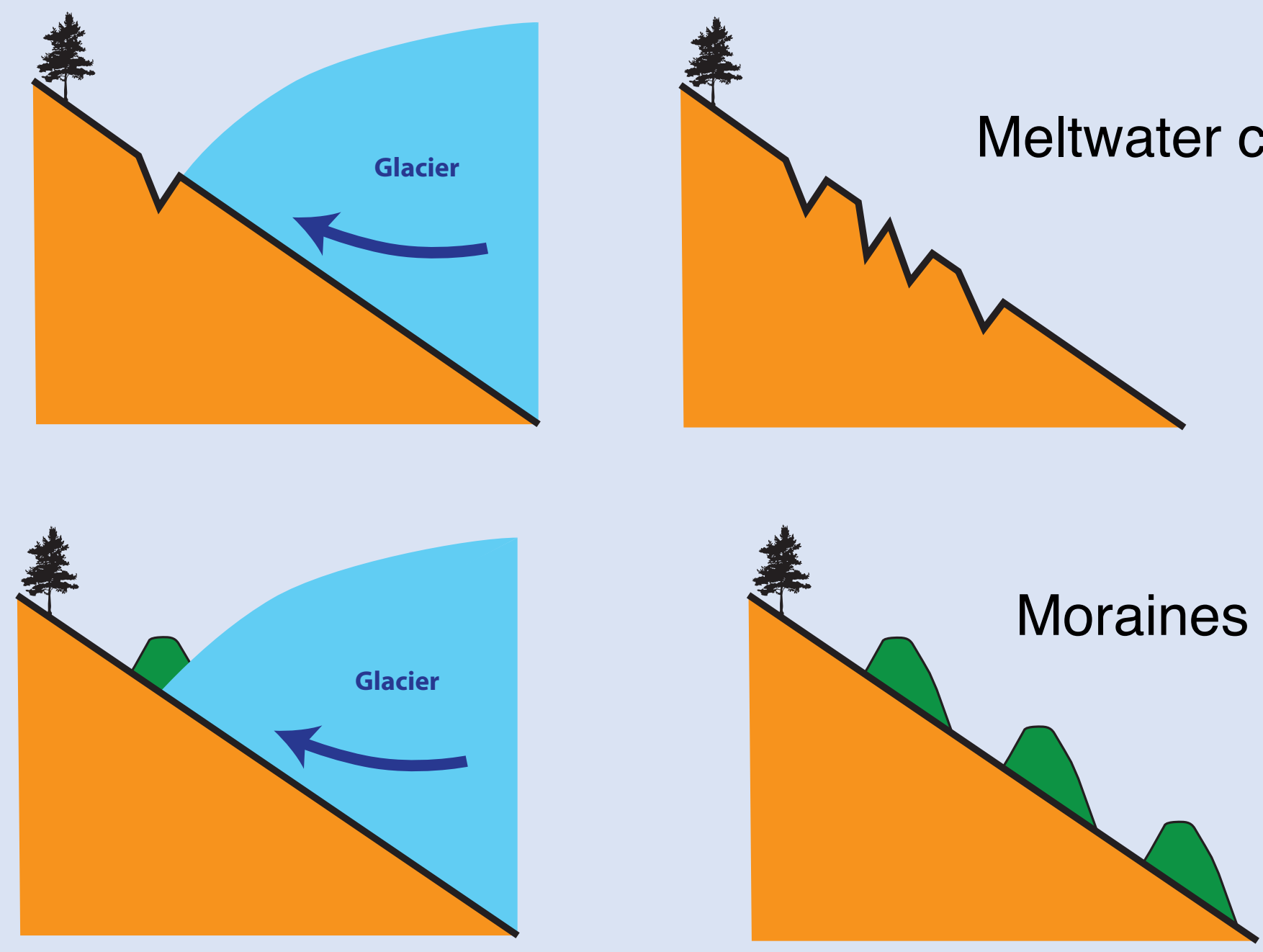


\section{Ice Margin Features}

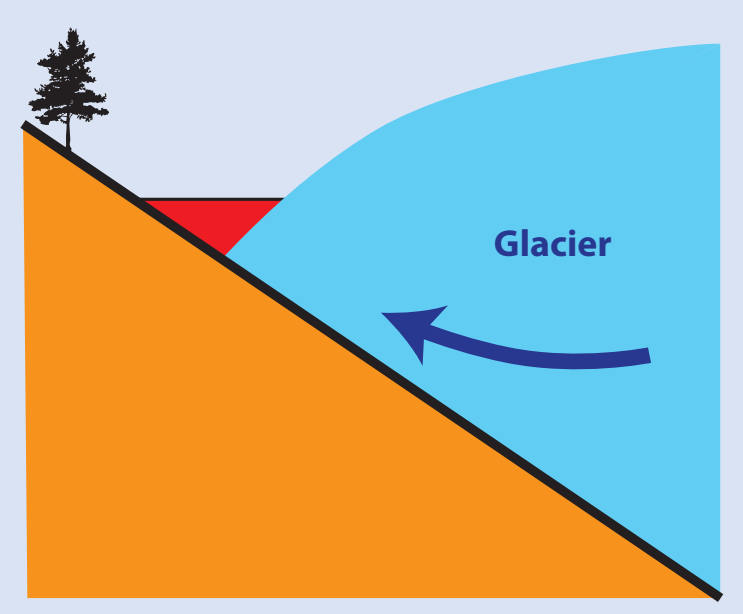

\section{Terraces}

All 3 mixed together

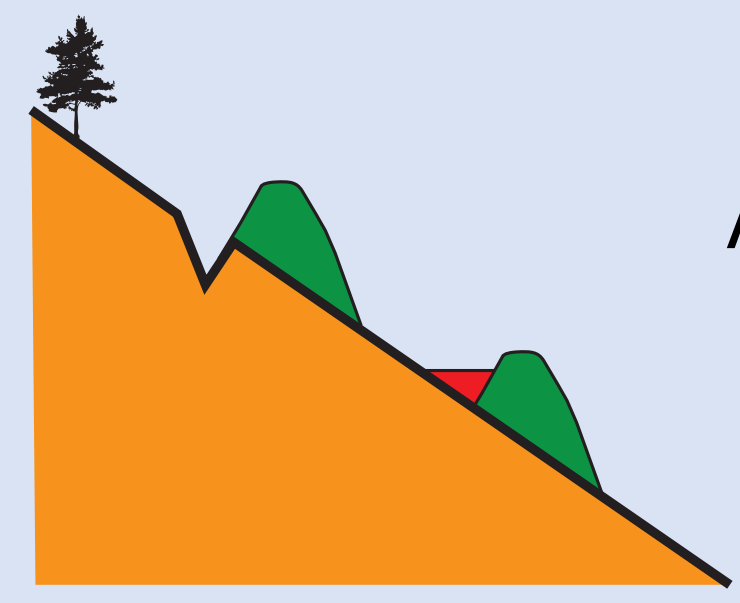




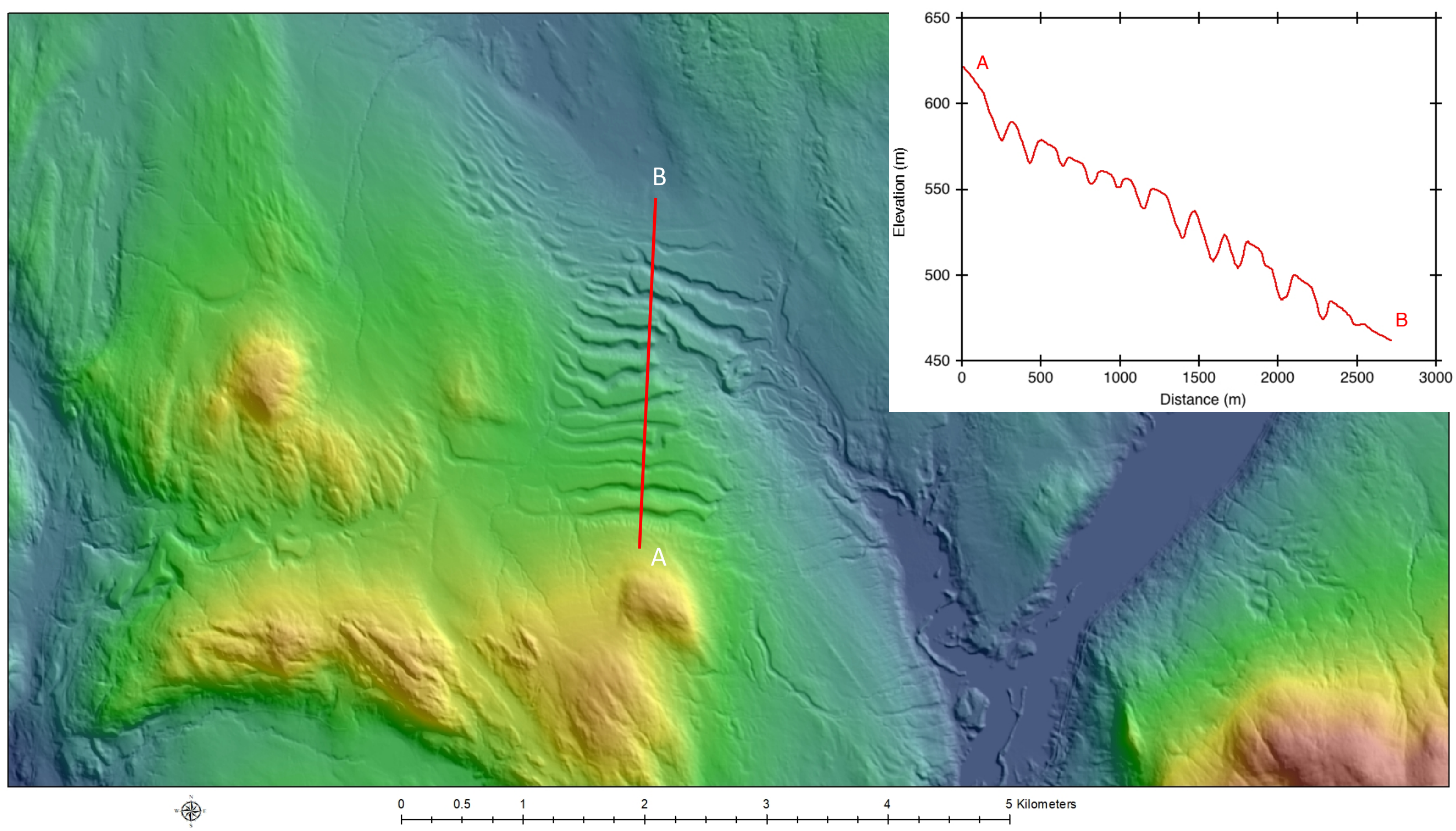




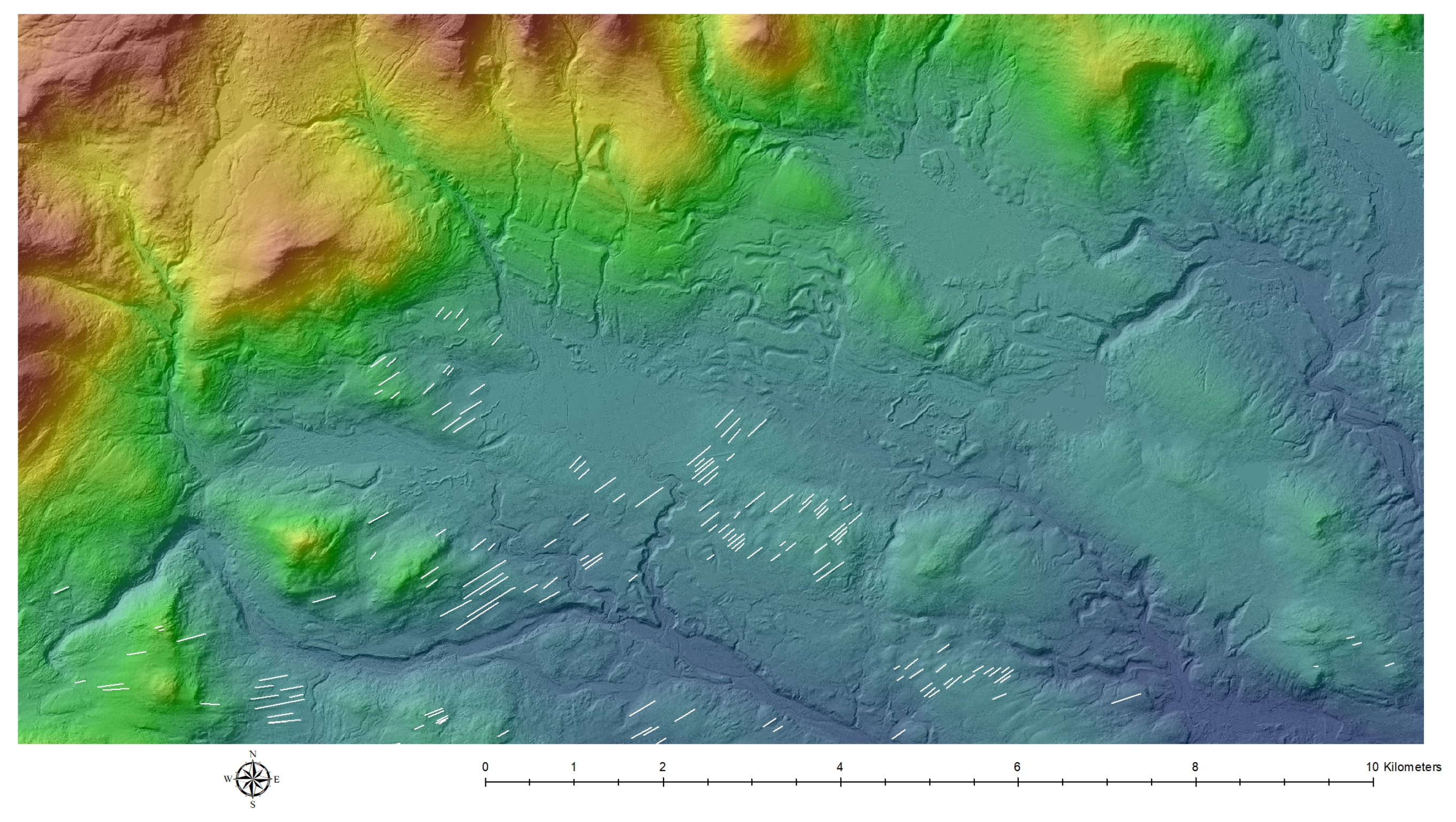




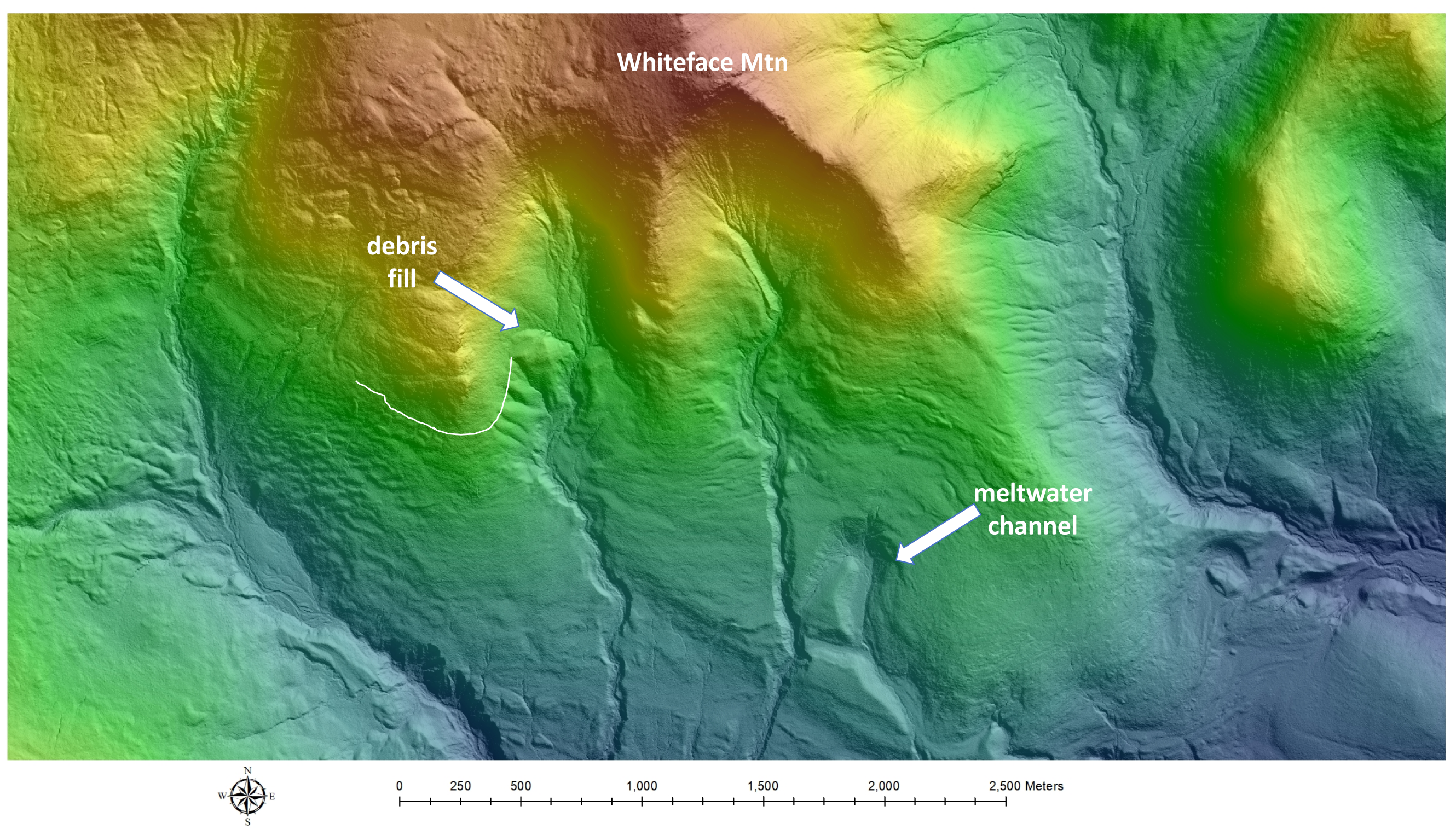




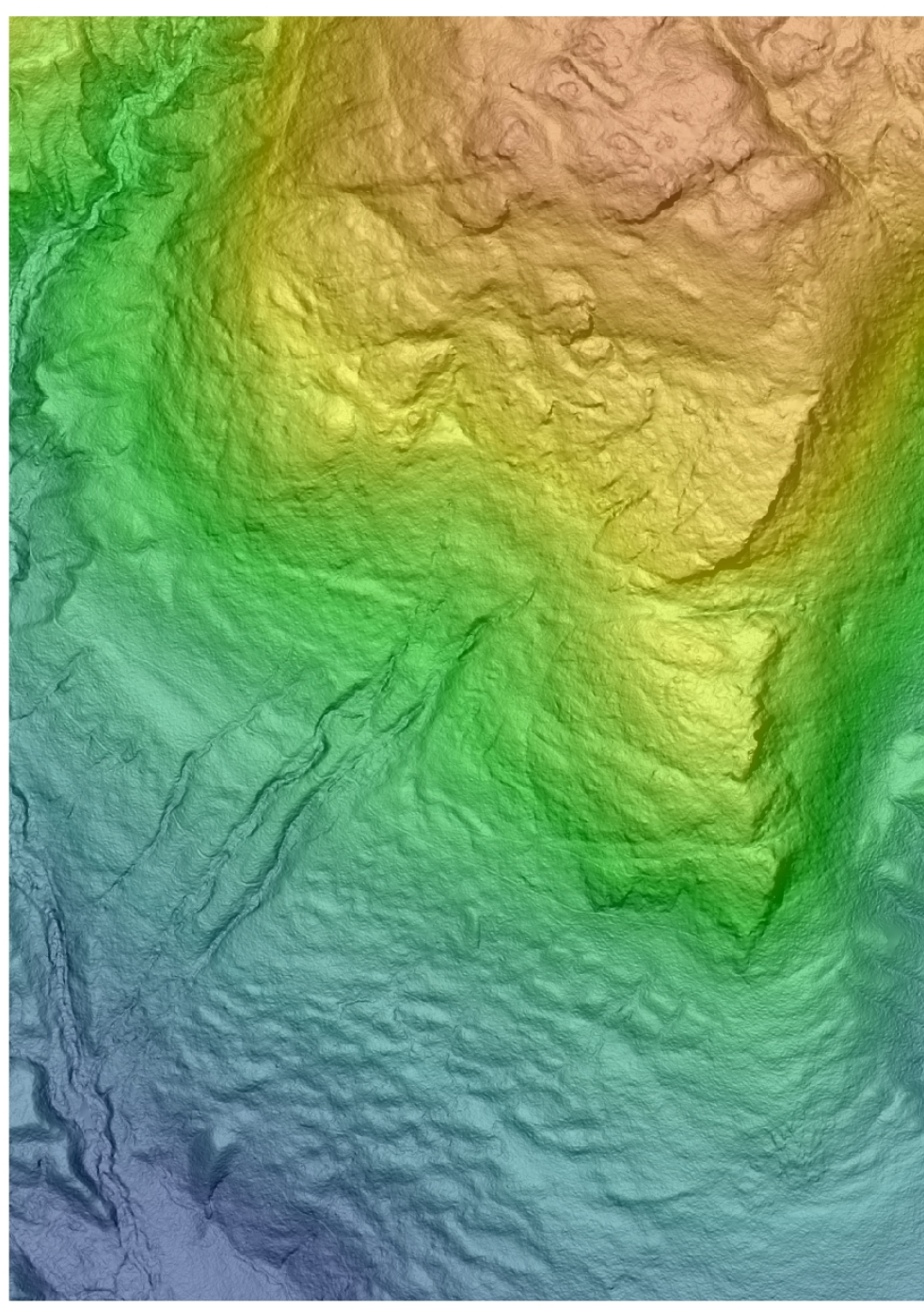

“艒
Whiteface

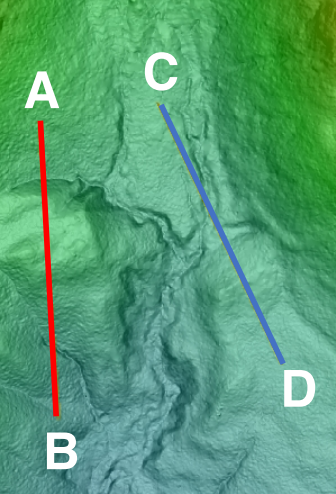

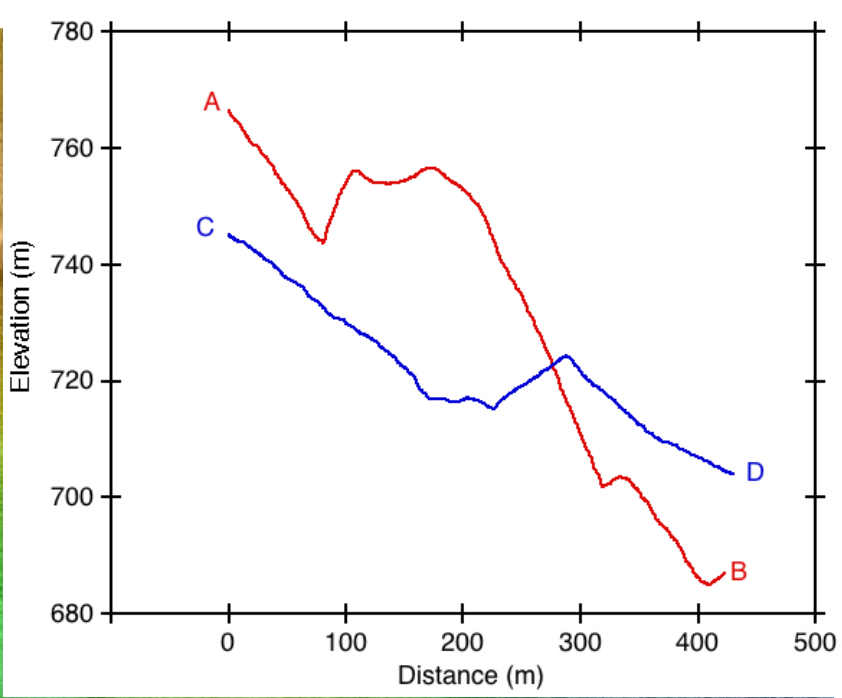
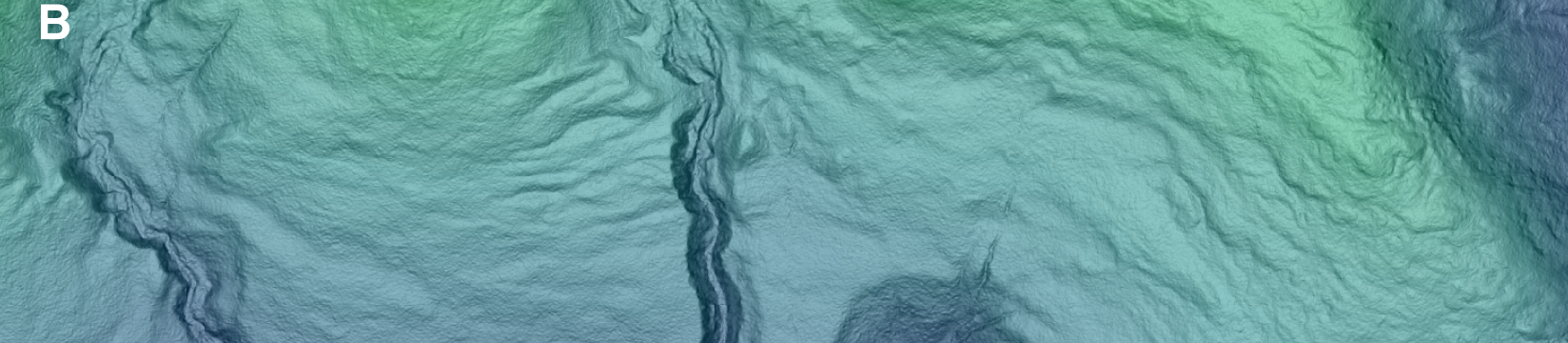

1,000

1,500

2,000 Meters 

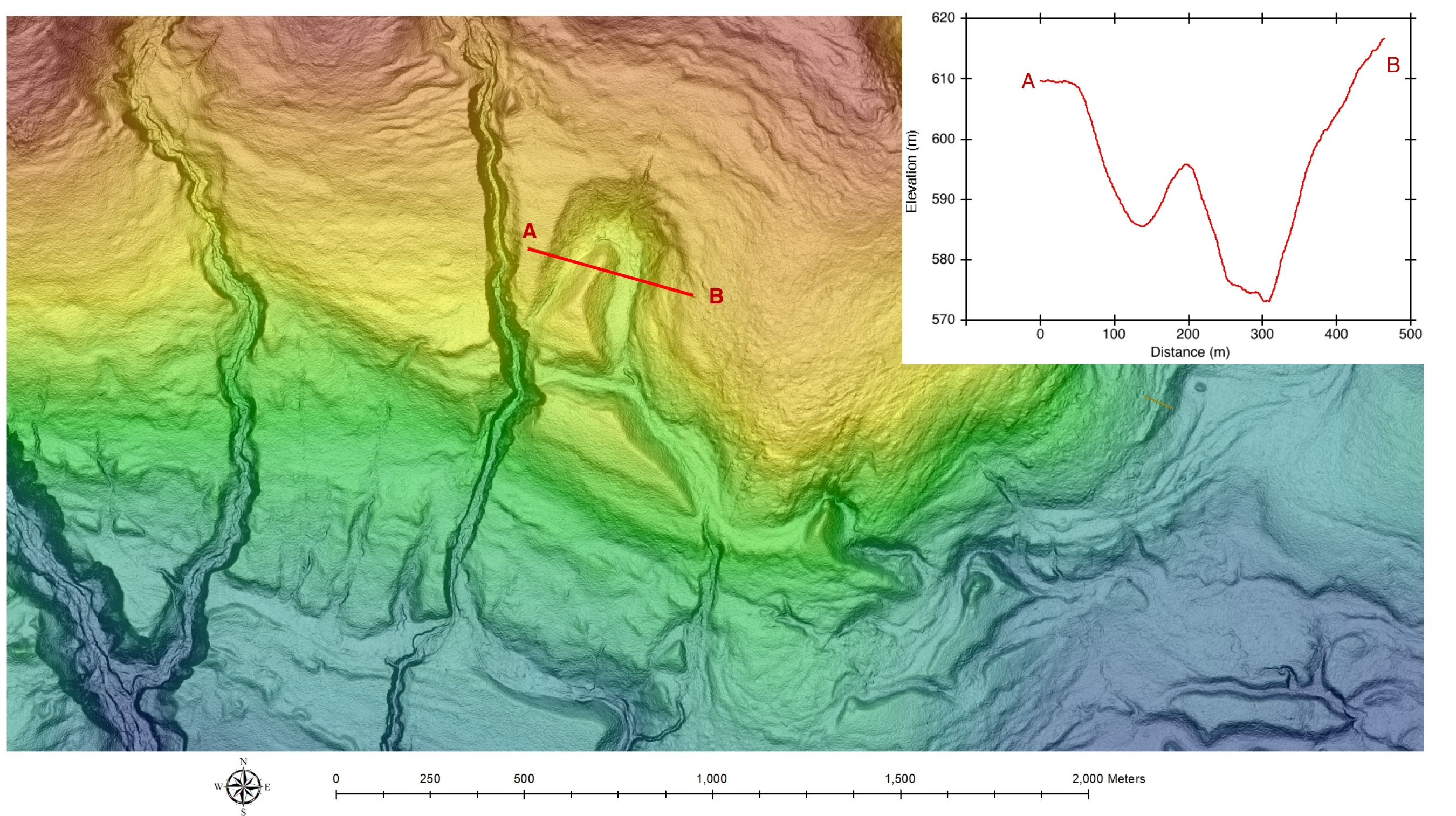


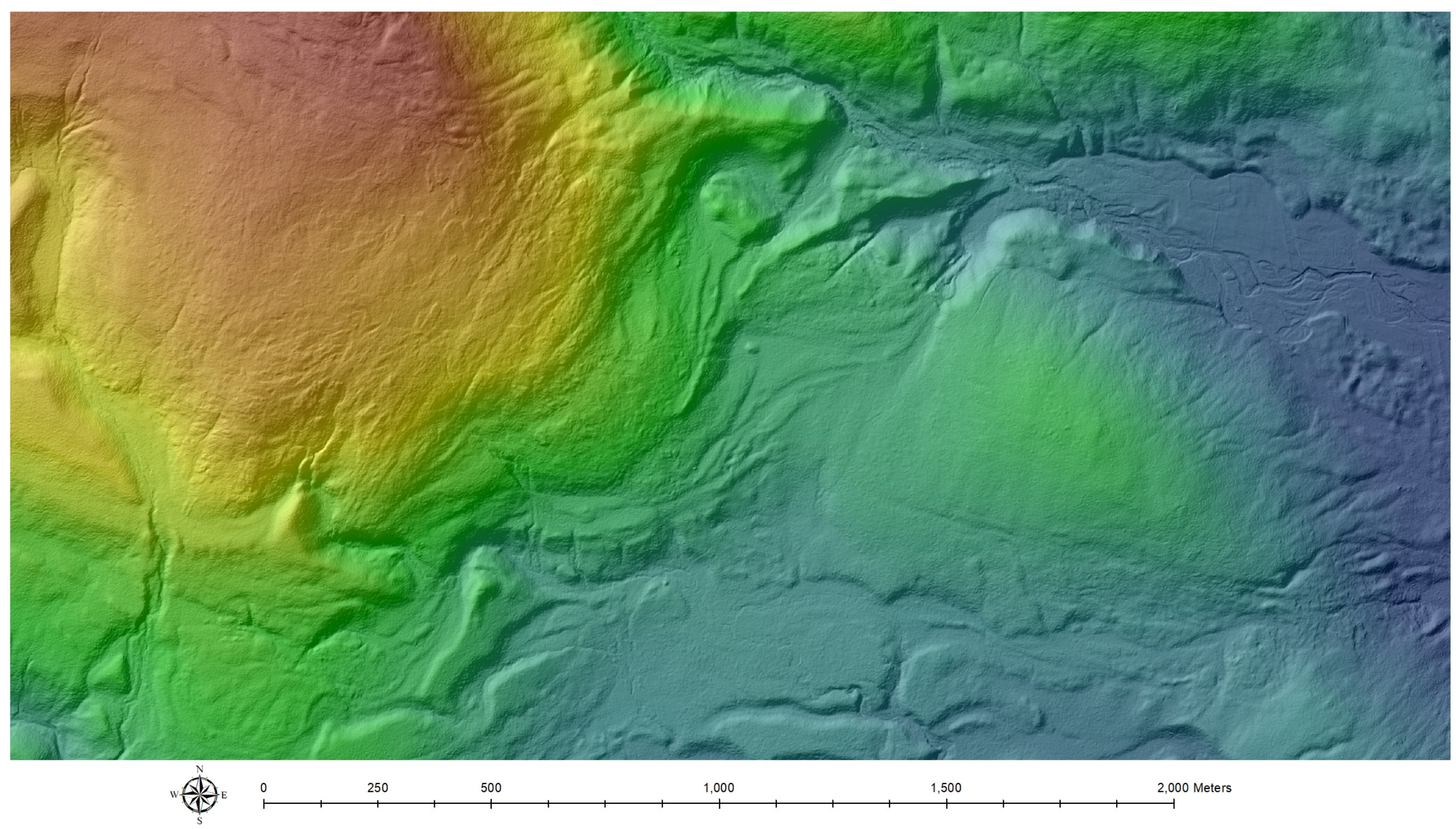



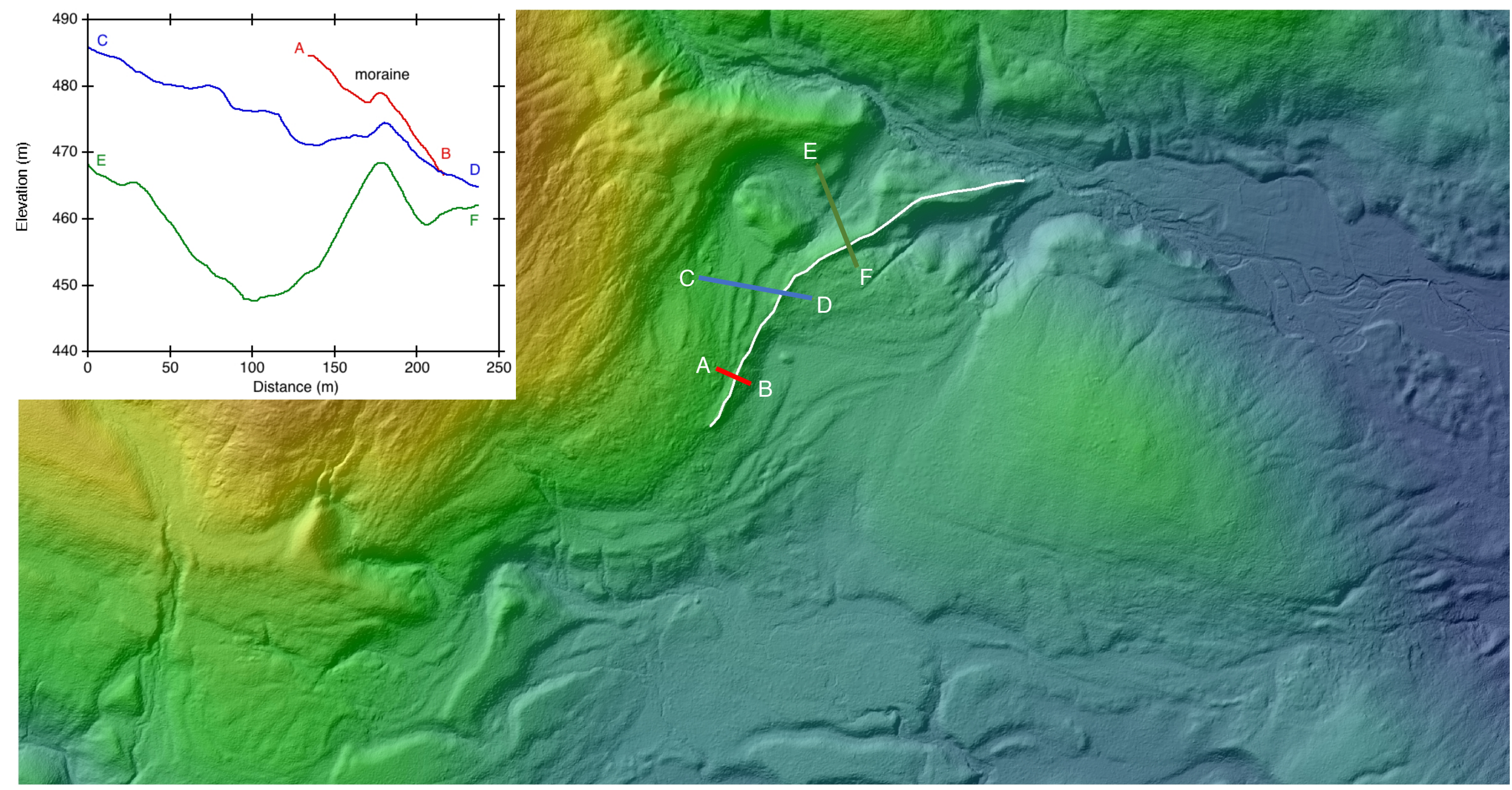

兽 


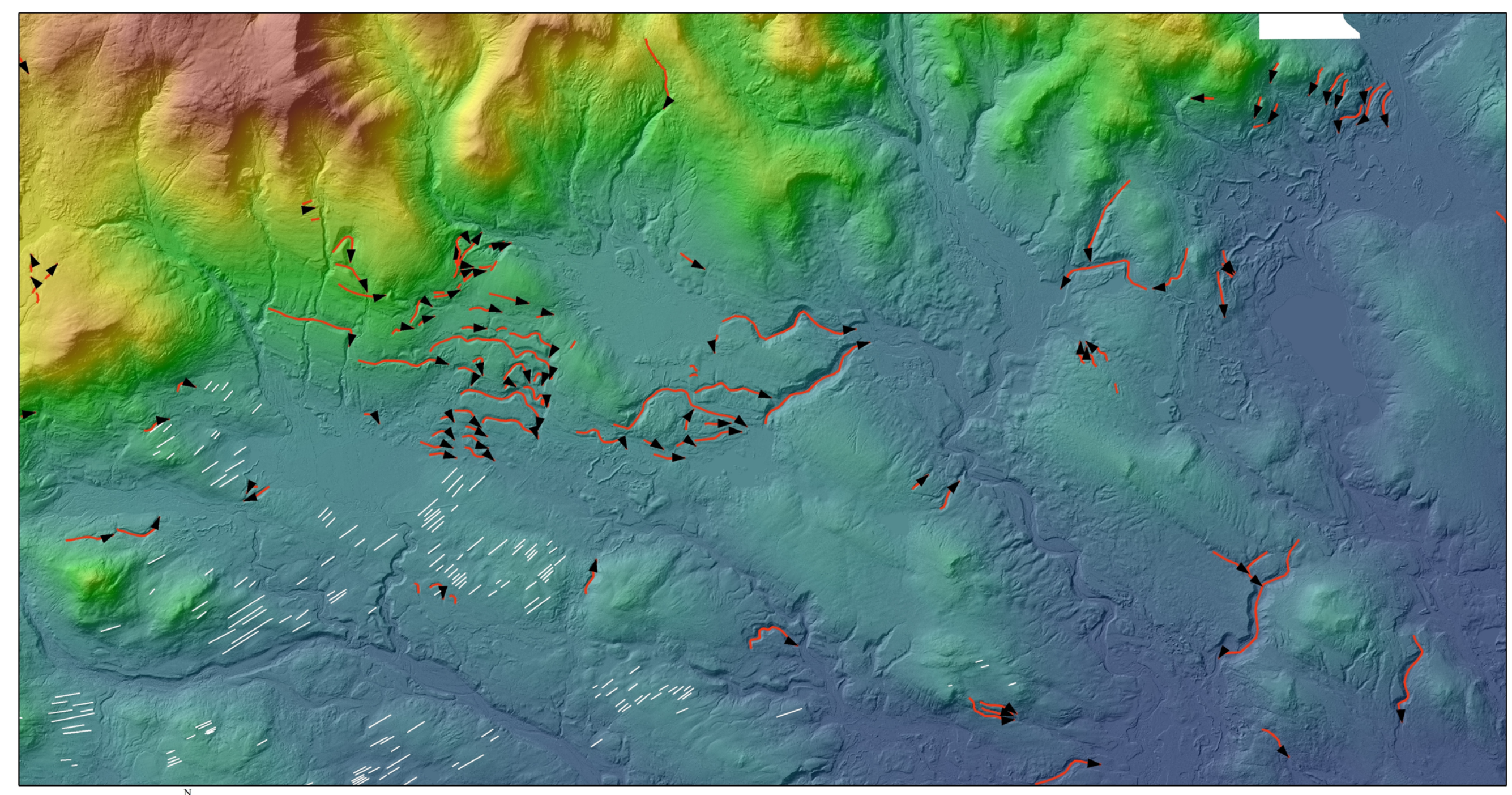

"零。

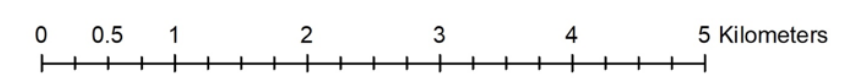




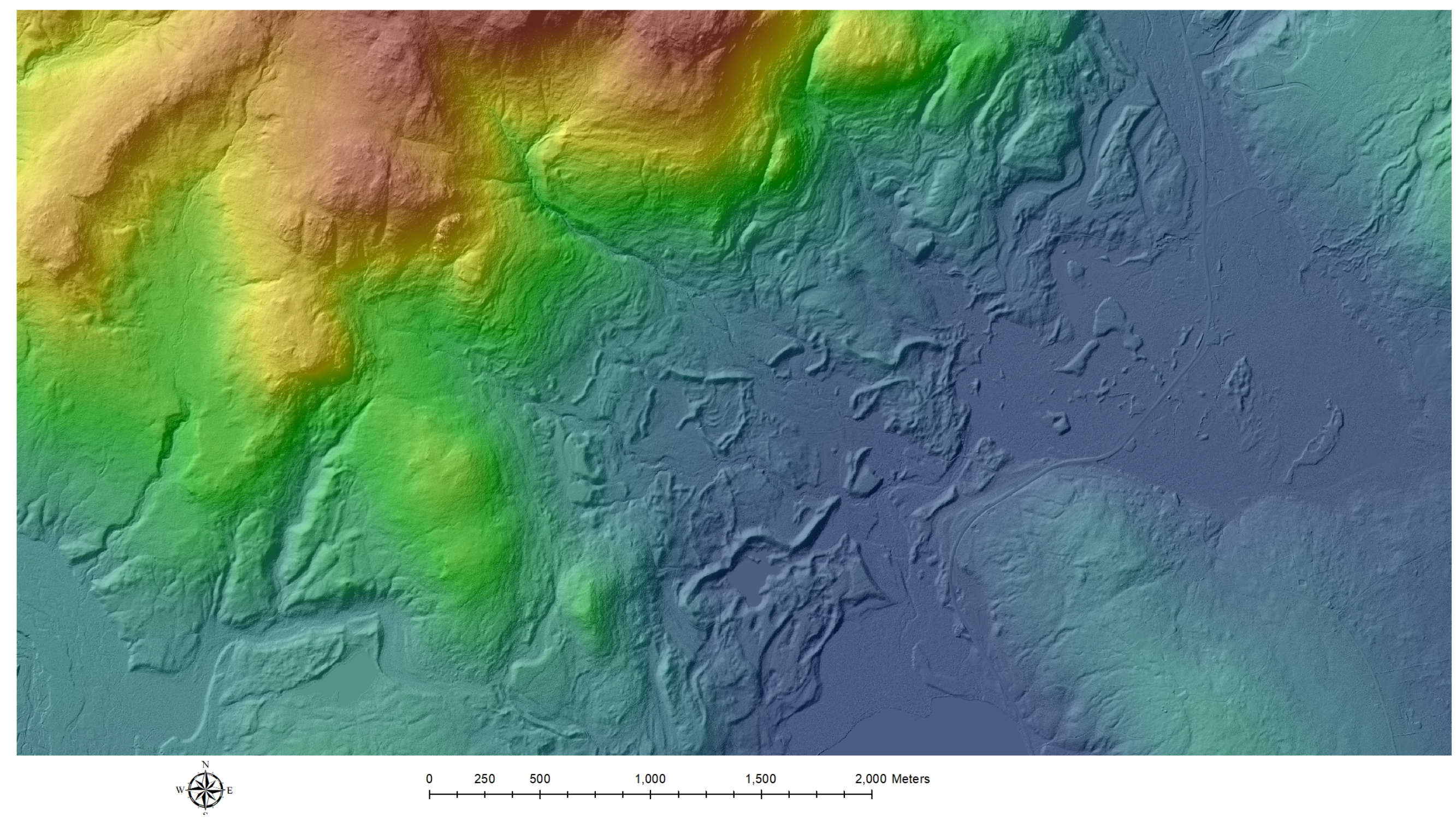




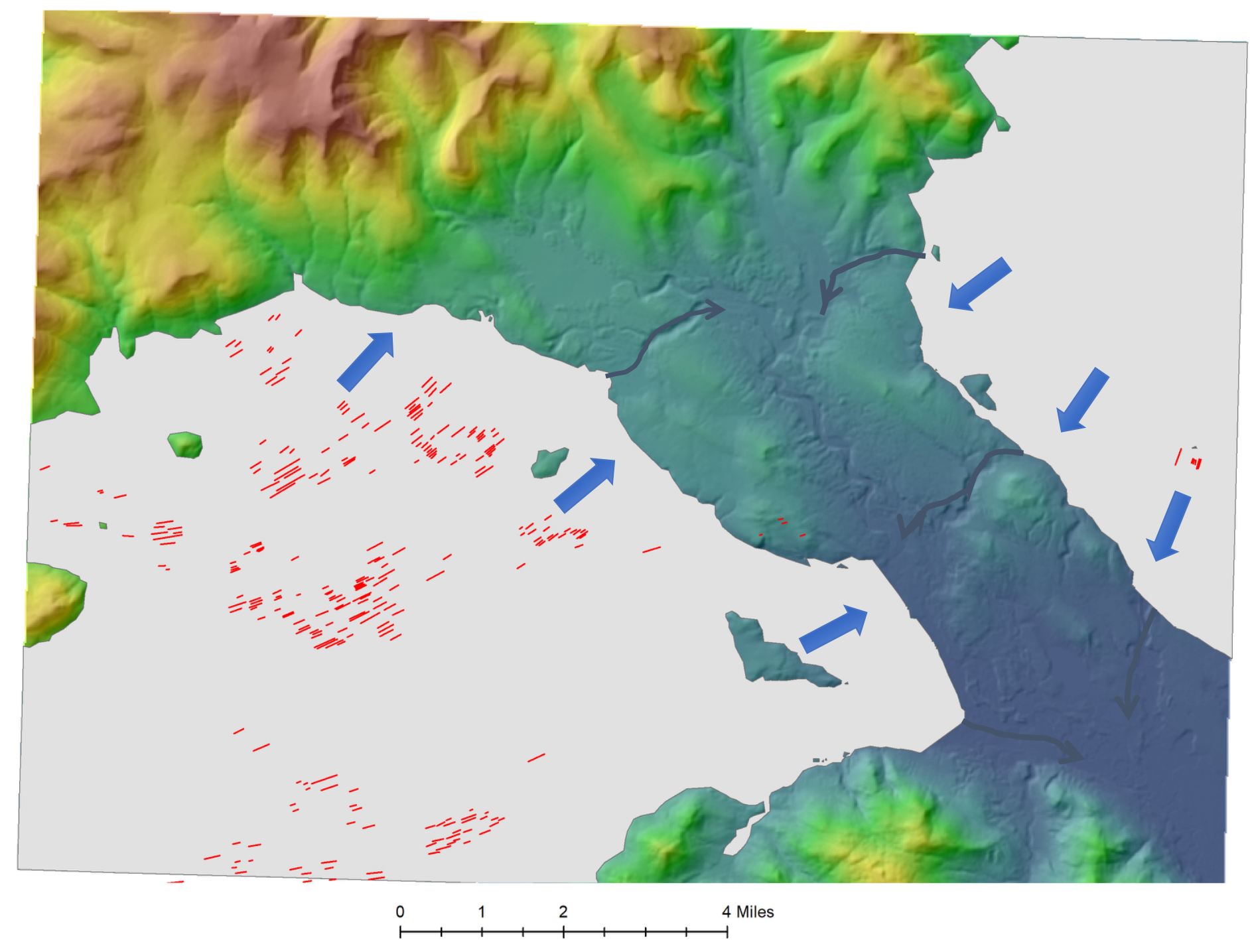




\section{Questions?}

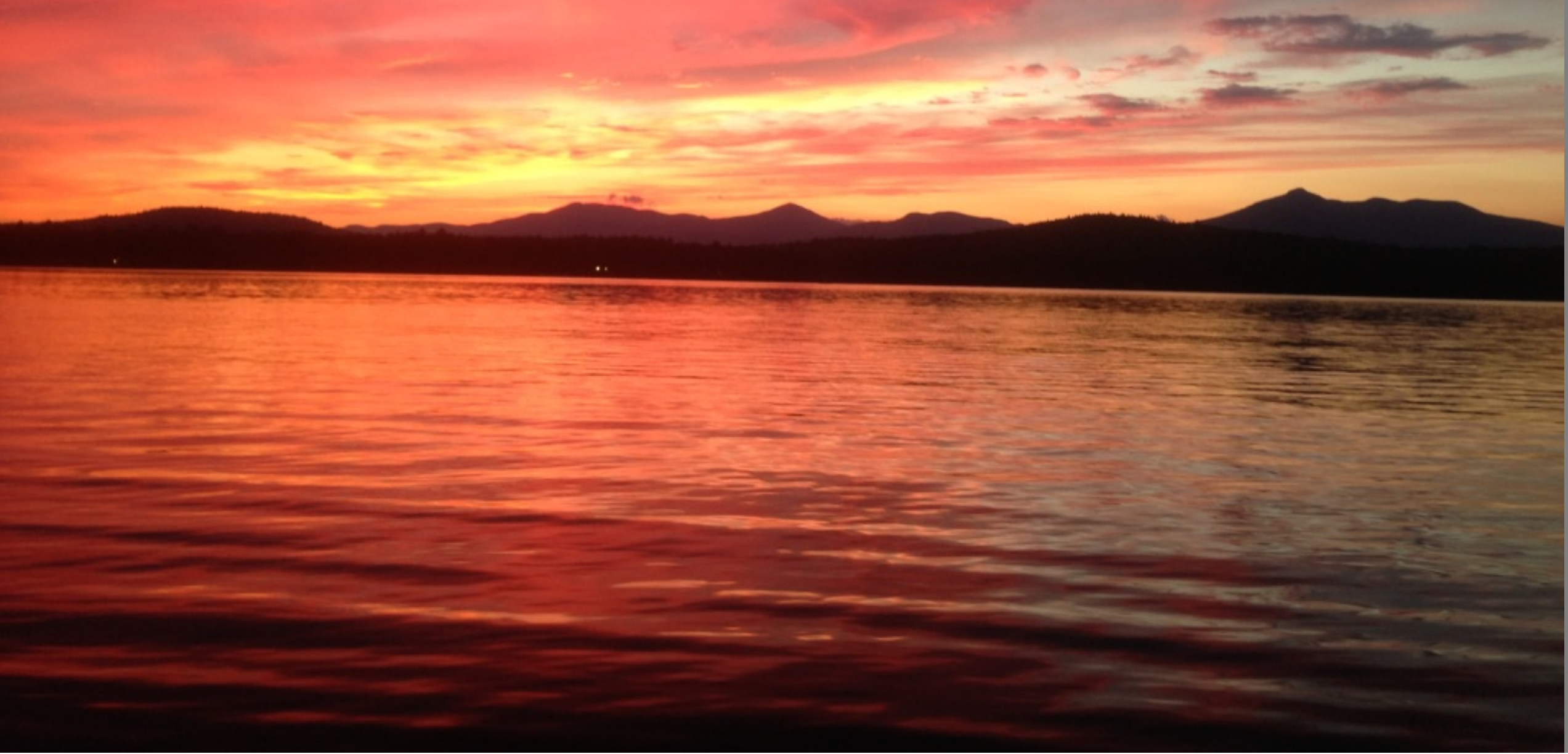

